Ks. STANISŁAW PIECH

\title{
KSIĘDZA MARIANA IGNACEGO MORAWSKIEGO POSEUGA MYŚLENIA
}

W bieżącym roku przypada setna rocznica śmierci ks. Mariana Ignacego Morawskiego, jezuity, pioniera i wybitnego przedstawiciela polskiej neoscholastyki, jednego $\mathrm{z}$ najwybitniejszych profesorów Uniwersytetu Jagiellońskiego schyłku XIX stulecia. Warto, korzystając z tej okazji przypomnieć tego niezwykłego myśliciela i teologa.

Marian Ignacy Morawski urodził się 15 sierpnia 1845 r. w Freiwaldzie (dziś Jesenik) na Śląsku austriackim. Był synem Wojciecha, właściciela Oporowa w Poznańskiem, później po owdowieniu, księdza i Marii Grocholskiej. Siudia z zakresu szkoły średniej z poczatkami filozofii i matematyki wyższej odbył w latach 1855-1863 w jezuickim kolegium Saint Clement w Metzu we Francji. W 1863 r. Morawski wstapił do Towarzystwa Jezusowego. Nowicjat odbył w Starej Wsi koło Krosna. Tam w latach $1865-1866$ studiował zasady wymowy. W 1866 r. rozpoczał w Starej Wsi kurs filozofii scholastycznej, który ukończył w 1868 r. w Krakowie, dokąd w 1867 r. przeniesiono całe studium filozofii i teologii jezuitów galicyjskich. Samodzielnie studiował filozofię Immanuela Kanta i René Descartesa. Zagadnienia naukowe omawiał także w korespondencji ze swoim bratem ciotecznym Franciszkiem Chłapowskim, lekarzem i przyrodnikiem, najbliższym swoim przyjacielem i powiernikiem. Na wykładach logiki i metafizyki wygłaszanych przez Camillo Tedeschiego dowiadywał się o próbach odrodzenia filozofii scholastycznej zapoczątkowanych przez Jaime Balmesa i kontynuowanych przez Jana Dmowskiego SI, profesora filozofii w Collegium Romanum. W latach 1868-1872 w okresie studiów teologicznych $\mathrm{w}$ instytucie zakonnym w Krakowie należał, wraz z księżmi Iwo Czeżowskim, wykładowcą teologii w kolegium na Wesołej i Stanisławem Stojałowskim, do redakcji "Tygodnika Soborowego" (8 I-15 VII 1870). Na czele redakcji stał ks. Zygmunt Golian, były profesor warszawskiej Akademii Duchownej, jeden z pierwszych Polaków, przedstawicieli kierunku neoscholastycznego w filozofii i teologii. Morawski na łamach „Tygodnika Soborowego" omawiał zagadnienia będące przedmiotem obrad Soboru Watykańskiego I, szczególnie zaś sprawę nieomylności papieża. Święcenia kapłańskie otrzymał 14 sierpnia $1870 \mathrm{r}$. w Śremie w Poznańskiem 1 .

${ }^{1}$ B. N a t o ń s k i, Morawski (Dzierżykraj-Morawski) Marian Ignacy, PSB, t. 21, s. 736-737; L. Grze bi én, Morawski Marian Ignacy, [w:], Stownik polskich teologów katolickich (dalej SPTK) t. 3, pod red, H. E. Wyczawskiego, Warszawa 1981, t. 3, s. 160-166 (bibliografia). 
Po rocznym kursie prawa zakonnego i praktyce ascetycznej, zwanej trzecia probacja, był w latach 1873-1879 wykładowcą filozofii w seminarium jezuickim w Starej Wsi. Morawski żywo interesował się duszpasterstwem prześladowanych przez rząd rosyjski unitów na Podlasiu. W Starej Wsi powziął zamiar zorganizowania wśród nich tajnej misji, zrealizowany z początkiem $1878 \mathrm{r}$. przez niefortunną wyprawę Henryka Jackowskiego SI. W 1882 r. brał udział w tworzeniu misji podolskiej wśród Rusinów. Sprawami unijnymi interesował się do końca życia. W 1879 r. został dyrektorem konwiktu w Tarnopolu. W okresie od 15 stycznia 1880 r. do 19 marca 1883 r. był rektorem tamtejszego kolegium. Był zwolennikiem szkoły wyznaniowej i humanistycznej, która „nie nęka uczniów filologia, ale pokazuje wzory"2.

W 1883 r. jezuici galicyjscy przejęli od ks. Edwarda Podolskiego „Przegląd Lwowski", wydawany przezeń od $1871 \mathrm{r}$. Od stycznia 1884 r. zaczęli go wydawać w Krakowie jako „Przegląd Powszechny”. Morawski został redaktorem naczelnym tego miesięcznika i przełożonym (superiorem) krakowskiego jezuickiego Domu Pisarzy. „Przegląd Powszechny” w zamyśle ks. Morawskiego miał „podnosić na wszelkim polu kwestie najaktualniejsze, a sprowadzać je do zasad, reasumować doniosłe wypadki i wybitne prądy myśli pojawiające się w kraju i po świecie, a dochodzić do ich gruntu i sądzić je rozumem oświeconym wiarą" ${ }^{, 3}$. Na łamach tego czasopisma, z wyjątkiem niewielu prac, opublikował wszystko co po objęciu jego redakcji w swoim życiu napisał. Tam drukował trzy swoje główne dzieła Celowość w naturze, Wieczory nad Lemanem i Świętych Obcowanie. Redaktorem „Przeglądu Powszechnego" był przez siedemnaście lat, aż do śmierci, wydając sześćdziesiąt dziewięć tomów.

\section{NA KATEDRZE UNIWERSYTETU JAGIELLOŃSKIEGO}

Ks. Marian Morawski postanowieniem cesarskim z dnia 14 listopada $1887 \mathrm{r}$. został mianowany profesorem teologii dogmatycznej szczegółowej w Uniwersytecie Jagiellońskim ${ }^{4}$. Zajęcia dydaktyczne rozpoczął $w$ semestrze zimowym 1887/88. W półroczach zimowych omawiał traktaty: $O$ Bogu jednym $i w$ Trójcy jedynym (De Deo Uno et Trino), O stworzeniu (De creatione), O grzechu pierworodnym (De peccato originali, 1888/89-1891/92), Odkupicielu (De Redemptore 1888/89, 1894/95-1897/98). W semestrach letnich zazwyczaj wykładał traktaty: $O$ Wcieleniu (De Incarnatione), O tasce (De gratia), sakramentach (de sacramentis) i o rzeczach ostatecznych (de novissimis). Traktat $O$ Wcieleniu był niekiedy omawiany w półroczu zimowym $(1892 / 93,1895 / 96,1897 / 98)$. Znany w środowisku akademickim Krakowa corocznie głosił wykłady publiczne. W roku akademickim 1888/89 wykładał $O$ nadprzyrodzonym porzadku. W na-

${ }^{2}$ B. N a to ń s k i, Morawski (Dzierżykraj-Morawski) Marian Ignacy, s. 737.

${ }^{3}$ M. Morawski, Cel $i$ zadanie "Przegladu Powszechnego", "Przegląd Powszechny" $1: 1884$, t. 1, s. 2.

${ }^{4}$ Archiwum Uniwersytetu Jagiellońskiego (dalej: AUJ), WT II 60, Ministerstwo Wyznań i Oświaty (dalej: Min. WiO) do Dziekanatu Wydziału Teologicznego Uniwersytetu Jagiellońskiego, Wiedeń 23 XI 1887. 
stępnym roku mówił $O$ Wcieleniu $i$ Odkupieniu. W półroczu zimowym 1890/91 wykładał $O$ Bogu jednym, a w letnim $O$ istnieniu Boga $i$ o doskonałościach Boskich. W latach 1891/92 i 1895/96 omawiał tajemnicę Eucharystii. W roku 1892/93 tematem była Eschatologia, czyli o rzeczach ostatecznych. W roku 1893/94 mówił O lasce. Następnym przedmiotem prelekcji był Dogmat stworzenia wobec nowożytnej filozofii. W latach 1896/97-1897/98 wykładał o sakramentach. Tematem jego ostatnich wykładów publicznych w Uniwersytecie Jagiellońskim była Osoba Chrystusa w dogmacie (1898/99) ${ }^{5}$. Wykłady te wygłaszane w języku polskim (na Wydziale Teologicznym teologię dogmatyczną wykładano po łacinie) były niezwykle popularne wśród młodzieży $\mathrm{z}$ innych wydziałów, która tłumnie wypełniała aulę ${ }^{6}$. Zachowały się notatki $\mathrm{z}$ dziewiętnastu jego wykładów publicznych o dogmacie łaski wygłoszonych w roku akademickim 1888/89, spisane przez jednego ze studentów. Rękopis ten przejrzał, uzupełnił, opatrzył przypisami i wydał jego bratanek Marian Morawski SI (1881-1940, późniejszy profesor nadzwyczajny teologii dogmatycznej w Katolickim Uniwersytecie Lubelskim, a następnie zastępca profesora tego przedmiotu w Uniwersytecie Jagiellońskim) jako książke Dogmat laski. 19. wykładów o „porządku nadprzyrodzonym". Z papierów pośmiertnych autora?.

Jakim człowiekiem i profesorem był ks. Morawski? „Do dziś, jako jeden z pierwszych jego słuchaczów, mam żywo w pamięci postać naszego kochanego profesora" - wspominał po latach profesor Uniwersytetu Jagiellońskiego ks. Franciszek Gabryl, jego uczeń. „Watty, nadzwyczaj żywy i ruchliwy w czasie wykładu, zachwycał nas polotem, filozoficznym pogłębieniem poruszanych zagadnień, swobodą nadzwyczajna, z jaką do nas się zbliżał, z życzliwością i miłościa jaką każdego z nas darzył. Miał zrazu niemało kłopotów z nami, i my z nim, bo swe wykłady ujmował $w$ formę scholastycznych dedukcji, do czego nie mielismy odpowiedniego przygotowania. Nie zrażał się jednak nasz profesor tymi brakami, lecz jak mógł, tak im zaradzał, pracował wytrwale nad ich usunięciem tak, że po przełamaniu pierwszych trudności czerpaliśmy pełnymi usty $\mathrm{z}$ czary jego wiedzy. Nieraz też musieliśmy biegać za naszym profesorem, bo w zapedzie swych myśli wybiegat $z$ sali wykładowej na ulicę bez nakrycia głowy"”.

"Wykłady jego nie były nigdy przeciążone balastem erudycji" - napisał Józef Tuszowski SI, jego biograf. „Oczytany w Ojcach Kościoła i w dziełach teologicznych, cytaty ograniczał do minimum. Natomiast przedmiot swoich wykładów podawał słuchaczom głęboko przez siebie przemyślany i przetrawiony. W jego ustach najtrudniejsze kwestie stawały się jasne i zrozumiałe. Jak Apostoł do Koryntian, mógł do swoich słuchaczów powiedzieć po każdym wykładzie: «Jak malutkim w Chrystusie, dałem wam mleko na napój, nie pokarm: boście jeszcze nie mogli» [por. 1 I Kor 3, 2]. Na wykładach posługiwał się luźnymi notatkami; zresztą zdawał się na swoją pamięć, która go nie zawodziła"'9".

${ }^{5}$ Spisy wykładów odbywać się majacych $w$ c.k. Uniwersytecie Jagiellońskim z lat 1887/88$-1898 / 99$.

${ }^{6}$ J. T u s z o w s k i, O. Marian Morawski TJ (1845-1901), Kraków 1932, s. 294.

${ }^{7}$ Kraków 1924.

${ }^{8}$ F. G a b r y l, Polska filozofia religijna w wieku XIX, t. 2, Warszawa 1914, s. 257.

${ }^{9}$ J. T u s z o w s k i, O. Marian Morawski..., s. 292. 
Ks. Morawski został profesorem zwyczajnym 19 stycznia $1891 \mathrm{r}^{10} \mathrm{~W}$ roku akademickim 1894/95 byi dziekanem Wydziału". Opracował projekt reformy studiów teologicznych w Uniwersytecie Jagiellońskim. Domagał się podniesienia poziomu nauczania w gimnazjach. Postulowat, aby studia filozoficzne i teologiczne były bardziej powiązane $\mathrm{z}$ aktualnymi potrzebami ludzkimi. W programie nauczania filozofii - jego zdaniem - winny były się znaleźć zagadnienia z zakresu etyki społecznej omawianej także w aspekcie historycznym. Wskazywał na potrzebę kształcenia fachowców w różnych dyscyplinach teologicznych. Zajmował się także reformą studiów zakonnych w galicyjskiej prowincji Towarzystwa Jezusowego.

\section{W TRUDZIE MYŚLENIA}

Ks. Marian Morawski - jeden z najwybitniejszych neoscholastyków europejskich był nie tylko głośnym filozofem, ale równocześnie znakomitym teologiem. Pierwsza jego poważniejsza praca filozoficzna, wydrukowana $w$ latach 1876-1877 w dwudziestu artykułach na łamach "Przeglądu Powszechnego", a następnie wydana w osobnej książce zatytułowanej Filozofia i jej zadanie ${ }^{12}$, przyniosła mu duży rozgłos stawiając go natychmiast $w$ rzędzie najwybitniejszych myślicieli polskich. W dziele tym omówił przyczyny upadku filozofii. Zarysowat historyczne prawa rozwoju systemów filozoficznych. Opowiadał się za kierunkiem empiryczno-idealnym w filozofii, którego najpełniejszy wyraz dostrzegał w neoscholastyce typu esencjalnego. Nawiazzywał do zdrowego rozsądku jako podstawy prawidłowego rozumowania przy równoczesnym braniu pod uwagę pokantowskiej i pozytywistycznej krytyki. Za Jaime Balmesem przyjmował kartezjański punkt wyjścia w filozofii z formalnymi zasadami tożsamości i oczywistości. W podziale metafizyki stosował schemat Christiana Wolffa. Bronił niezależności fillozofii od teologii podkreślając, że różnica między nimi jest w podmiotowym powodzie poznania (powaga - w teologii, wewnętrzna przyczyna w filozofii) ${ }^{13}$. Zarówno punkt wyjścia w filozofii jak i wyraźne opowiedzenie się za neoscholastyką wywołało gorąca polemikę ze Stefanem Pawlickim CR, głównym w owym czasie przeciwnikiem odrodzenia scholastyki ${ }^{14}$. Spór dotyczył rozumienia filozofii, stosunku filozofii do teologii, możliwości zbudowania i usprawnienia metafizyki jako nauki o bycie. Głównym jednak przedmiotem sporu była ocena scholastyki jako faktu historycznego, możliwości i potrzeba jej odnowy na gruncie myśli współczesnej ${ }^{15}$. Owocem tej dyskusji było dokładniejsze

${ }^{10}$ AUJ, WT II 65, Min. WiO do Dziekanatu Wydz. Teolog. UJ, Wiedeń 24 I 1891.

${ }^{11}$ S. P i e c h, Dzieje Wydziału Teologicznego Uniwersytetu Jagiellońskiego, s. 79, 229.

${ }^{12}$ Lwów 1877 , Kraków $1899^{3}$.

${ }^{13}$ B. D e mb ow s k i, Spór o metafizyke. Główne poglady na metafizyke w Polsce na przetomie $X L X$ i $X X$ w., Warszawa 1969, s. 38-81; B. N a to ń s k i, Morawski (Dzierżykraj-Morawski) Marian Ignacy, s. 737.

14 Por. S. P a w l i ck i, Ks. Mariana Morawskiego "Filozofia i jej zadania”, „Przegląd Polski”" 12:1878, t. 3, s. 382-402; M. M or a w s k i, Kilka slów o ksiqżce "Filozofia i jej zadania", „Przegląd Lwowski” 1878, t. 15, s. 541-555, 602-619.

${ }_{15}$ C. G $t$ o m b i k, Poczqtki neoscholastyki polskiej, Katowice 1991, s. 201-202, 224-225. 
wyjaśnienie charakteru neoscholastyki. Morawski będąc wykładowcą filozofii w Starej Wsi pracował nad dziełem Filozofia natury. Odrzucał hylemorfizm, a przyjmował teorię atomistyczno-dynamiczna, Pracę nad tą książką bezpowrotnie przerwał, gdy papież Leon XIII w ogłoszonej w 1879 r. encyklice Aeterni Patris zalecił neoscholastykom przyjęcie materii pierwszej i formy substancjalnej (hylemorfizm) ${ }^{16}$. Przeniesiony do Tarnopola $\mathrm{z}$ „wielkim żalem” rozstawał się ze studentami, „, bo praca na polu filozofii była mu ze wszystkich najmilsza”. Po latach surowo oceniał swoje pierwsze dzieło Filozofia $i$ jej zadanie, nazywając je żartobliwie „mon péché de jeunesse" ${ }^{\text {17 }}$.

Poświęcając wiele miejsca wzajemnej relacji nauki i wiary na łamach redagowanego przez siebie „Przeglądu Powszechnego”, stał się twórca nowego w Polsce rodzaju piśmiennictwa teologicznego zwanego literaturą światopoglądową. Ten typ pisarstwa narodził się we Francji, gdzie jej znanym reprezentantem był François René de Chateaubriand. Z tego względu ks. Aleksy Klawek w swoim Zarysie dziejów teo-

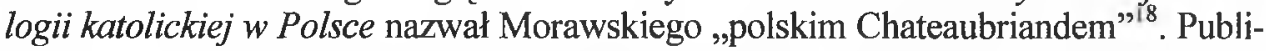
cystyka Morawskiego odznaczała się dużymi walorami literackimi. Początkowo podejmował zagadnienia filozoficzne pozostające w związku z tezami pozytywizmu. Pod wpływem pracy Paula Janeta Les causes finales ${ }^{19}$ zajął się na łamach „Przeglądu Powszechnego" problemem celowości przedmiotowej w świecie. Były to na nowo przezeń przemyślane i popularnie ujęte rozdziały ze wspomnianej wyżej nie ukończonej pracy Filozofia natury. Poglądy Morawskiego spotkały się z ostrą krytyką ze strony Adama Mahrburga. Polemizował z nimi także Aleksander Skórski. Artykuły te, zebrane razem, zostały wydane w książce Celowość w naturze. Studium przyrodniczo-filozoficzne $e^{20}$.

Morawski interesował się frapującym współczesnych problemem stosunku nauk przyrodniczych do wiary. Wychodząc z ogólnie już wtedy przyjętej definiçji nauk przyrodniczych, ich przedmiotu, metody i zakresu badań udowodnit, że nie moga one rozstrzygać zagadnień światopoglądowych i religijnych. Wykazał tym samym, że nie można przeciwstawiać sobie wiary i nauk przyrodniczych. Te ostatnie mogą co najwyżej kierunkiem swych badań zbliżać lub oddalać od wiary religijnej. Poglądy te stawiały Morawskiego w gronie nielicznych wówczas prekursorów dzisiejszych rozwiązań tego pasjonującego zagadnienia ${ }^{21}$.

W myśli filozoficznej Morawskiego wiele miejsca zajmowały zagadnienia etyczne. Już w Starej Wsi na wykładach etyki w roku akademickim 1877/78 przedstawił pozytywny i tradycyjny model nauki moralności ujętej esencjalnie. Na łamach „Przeglądu Powszechnego" publikował drobne rozprawki „pisane pod wpływem różnych okoliczności; zawsze jednak $\mathrm{z}$ tą myślą żeby się złożyły kiedyś w całość, i zawsze z tą dążnością żeby sprowadzać aktualne wypadki do podsta-

${ }^{16}$ B. D e m bow ski, Spór o metafizyke, s. 81; B. N a to ń s k i, Morawski (Dzierżykraj-Morawski) Marian Ignacy, s. 737; J. T u s z o w s k i, O. Marian Morawski.., s. 182.

${ }^{17} \mathrm{~J}$. T u s z o w s k i, O. Marian Morawski..., s. 183.

${ }^{18}$ A. K 1 a w e k, Zarys dziejów teologii katolickiej w Polsce, Kraków 1948, s. 29.

${ }^{19}$ Paris 1882.

${ }^{20}$ Kraków $1887,1928^{6}$.

${ }^{21}$ A. B y s tr y, Wiara a nauki przyrodnicze w ujęciu ks. Mariana Morawskiego TJ, „Poznańskie Studia Teologiczne" I :1972, s. 308-310. 
wowych zasad etyki”22. Rozważał w nich zagadnienia etyki indywidualnej. Artykuły te zebrane razem wydał w osobnej ksiażce zatytułowanej Podstowy etyki i prawa $a^{23}$, wymierzonej przeciw determinizmowi i pozytywizmowi. Dużo miejsca poświęcił zagadnieniu wolnej woli jako warunku moralności. Morawski należał do pierwszych polskich jezuickich filozofów, którzy podkreślali znaczenie prawa naturalnego, jego niezmienny charakter i siłę wiążąca. W świetle prawa naturalnego starał się rozwiązywać szczegółowe problemy społeczne i narodowościowe.

$\mathrm{Na}$ gruncie nauk społecznych żywo interesował się solidaryzmem, zwłaszcza jego filozoficznym uzasadnieniem. Znaczny wpływ na te zainteresowania wywarł Henri Marion swoją książką: De la solidarité morale. Essai de psychologie appliquée ${ }^{24}$. W myśli Morawskiego solidarność fizjologiczna i moralna między ludźmi stanowi podstawę tajemniczej spójni zwanej communio sanctorum. Zamierzał napisać dużą pracę o świętych obcowaniu. Nie bez wpływu na powzięcie tego zamiaru były jego wykłady uniwersyteckie „o łasce”, dla których studiował materiały źródłowe i dotychczasową literaturę o dogmacie świętych obcowania. W dziele tym zamierzał przystępnie omówić tę spójnię, określić jej podstawę i sposób zjednoczenia ludzi przez Kościół. Zdołał jednak tylko częściowo uporać się z pierwszą kwestią: faktem istnienia mistycznej solidarności. Dowody czerpał z literatury i sztuki pierwszych wieków chrześcijaństwa. Przemyślenia te odznaczające się nowatorstwem ujęcia, zwłaszcza w kwestii istoty Kościoła i źródeł do jej poznania, publikował w „Przeglądzie Powszechnym” w latach 1899-1901. Po jego śmierci artykuły te wydano w osobnej odbitce zatytułowanej Świętych Obcowanie, cz. 1. Komunia między duszami ${ }^{25}$.

Z problematyką filozoficzną łączył zainteresowania apologetyka, która znajdowała się zawsze na przejściu od refleksji filozoficznej, poszukującej sensu świata i człowieka, do refleksji teologicznej, badającej pod okiem Urzędu Nauczycielskiego Kościoła treść nauki objawionej. Na polu apologetyki osiagnął Morawski poziom europejski. Podstawę wyjątkowej jego pozycji w dziejach polskiej myśli apologetycznej stanowiło przede wszystkim oparcie się na klasycznym już wtedy trójczłonowym schemacie traktującym o religii, objawieniu chrześcijańskim i o Kościele katolickim ${ }^{26}$. W Wieczorach nad Lemanem, drukowanych w latach 1893-1896 na łamach „Przeglądu Powszechnego", po mistrzowsku przeprowadził uzasadnienie tej nauki w szacie słownej o wysokich walorach literackich. W pracy tej wielokrotnie później wydawanej w postaci książkowej jasno i gruntownie w formie dialogu o dużym napięciu dramatycznym stworzył swoistego rodzaju zarys filozofii religii o charakterze apologetycznym. Nie zamierzał bowiem pisać obszernej, ściśle naukowej apologetyki opartej na najnowszych osiagnięciach nauki. „Nie zakreślam wcale tej ksiazżce szerokiego planu i zadania apologetyki; - pisał Morawski w słowie do czytelnika - szukam tylko pewnej skróconej drogi, po której by umysły nowożytnego kroju, [...] dojść mogły do

${ }^{22}$ M. M o r aw s k i, Podstawy etyki i prawa, Kraków 1908, s. 207.

${ }^{23}$ Kraków 1891, $1930^{4}$.

${ }^{24}$ Paris 1880.

${ }^{25}$ Kraków 1903, 19233.

${ }^{26}$ S. N a g y, Apologetyka polska, [w:] Dzieje teologii katolickiej w Polsce, pod red. M. Rechowicza, t. 3, cz. 1, Lublin 1976, s. 199-200. 
przekonan, jakich potrzebuja"27. Ta „skrócona droga” szukających Boga kończyła się w „bramie katolicyzmu" ${ }^{28}$. Wieczory nad Lemanem były niezwykle popularne i przyniosły ks. Morawskiemu największy rozgłos. Dziełko to doczekało się dwunastu wydań w języku polskim i szesnastu w językach obcych (w niemieckim - siedem wydań i po jednym w angielskim, chorwackim, francuskim, hiszpańskim, holenderskim, portugalskim, rosyjskim, węgierskim, a nawet japońskim).

Profesor wykorzystywał „każdą chwilę bieżąca. O przyszłość się nie troszczył; składał ją w ręce Opatrzności i przełożonych" ${ }^{29}$. Nadmiar pracy mścił się jednak na jego zdrowiu. Kiedy ono, mimo częstych kuracji $u$ wód krajowych i zagranicznych, nie ulegało poprawie, poprosił z końcem marca 1899 r. o zwolnienie z zajmowanej przez siebie katedry teologii dogmatyki szczegółowej. Dnia 1 sierpnia 1899 r. został przeniesiony w stan spoczynku. Schorowany zmarł dnia 6 maja 1901 r. w Krakowie. Ks. Marian Ignacy Morawski SI profesorem Uniwersytetu Jagiellońskiego był zaledwie 12 lat. Były to lata wielkiego wysiłku myśli płodnego w dzieła, do których mimo upływu sporego już czasu, jeszcze dziś sięgają filozofowie i teologowie.

${ }^{27}$ M. M o r a w s k i, Wieczory nad Lemanem, Warszawa $1938^{9}$, s. 9.

${ }^{28}$ J. M aj kow ski, Filozofia religii o. Mariana Morawskiego 1845-1901, "Przegląd Powszechny" 69:1952, t. 234, s. 156.

29 J. T u s z o w s k i, O. Marian Morawski.., s. 295. 